\title{
İşletmelerin Vizyon Bildirimlerinin Stratejik Yönden İncelenmesi: BİST Sürdürülebilirlik Endeksinde Yer Alan Firmalara Yönelik Bir İçerik Analizi (A Strategic Investigation of the Vision Notifications of Companies: A Content Analysis For The Companies In The BIST Sustainability Index)
}

\author{
Safa ACAR IDa \\ a Kurtalan Yüksekokulu, Siirt Üniversitesi, Kurtalan, Siirt, Türkiye. safaacar@siirt.edu.tr
}

\begin{tabular}{|c|c|}
\hline MAKALE BİLGİsi் & ÖZET \\
\hline $\begin{array}{l}\text { Anahtar Kelimeler: } \\
\text { Vizyon } \\
\text { BİST Sürdürülebilirlik Endeksi }\end{array}$ & $\begin{array}{l}\text { Amaç - Çalışmanın amacı vizyon bildirimi kavramının önemini vurgulayarak işletmelerin } \\
\text { vizyon bildirimlerini amacına uygun olarak uygulayıp uygulamadığını tespit etmektir. } \\
\text { Çalışmanın ana sorusu "İşletmeler vizyon ifadeleri içerisinde vizyon bildiriminin içinde } \\
\text { bulunması gereken değerlerin ne kadarını bulundurmaktadırlar?" şeklinde ifade edilmiştir. }\end{array}$ \\
\hline Gönderme Tarihi 14 Kasım 2018 & $\begin{array}{l}\text { Yöntem - BİST Sürdürülebilirlik Endeksinde } 2018 \text { yılında yer alan } 50 \text { firmanın kendi internet } \\
\text { sitelerinde yer verdikleri vizyon ifadeleri nitel analiz yöntemlerinden olan içerik analizine tabi } \\
\text { tutulmuştur. }\end{array}$ \\
\hline $\begin{array}{l}\text { Revizyon Tarihi } 16 \text { Şubat } 2019 \\
\text { Kabul Tarihi } 20 \text { Şubat } 2019\end{array}$ & $\begin{array}{l}\text { Bulgular -Yapılan analizlerde } 50 \text { firmanın tamamının vizyon ifadesine sahip olduğu ve } \\
\text { kıyaslama ölçütü olarak alınan } 7 \text { öğeden en az } 4 \text { tanesine yer veren işletmelerin sayısının } 40 \\
\text { olduğu görülmüştür. Bu sayı işletmelerin vizyon ifadesine önem verdiklerini göstermektedir. }\end{array}$ \\
\hline $\begin{array}{l}\text { Makale Kategorisi: } \\
\text { Araştırma Makalesi }\end{array}$ & $\begin{array}{l}\text { Tartışma - İşletmeler, içinde bulundukları rekabetçi ortamlardan sıyrılıp uzun ömürlü bir } \\
\text { yapıya dönüşebilmek için stratejik yönetim değerlerini kullanmalıdır. Bu değerler içerisinde yer } \\
\text { alan vizyon ifadesi, geleceğe yön veren bir değer olarak büyük öneme sahiptir. Çalışmada } \\
\text { analiz edilen firmaların bir çoğunun da vizyon ifadesine büyük önem verdiği görülmektedir. }\end{array}$ \\
\hline
\end{tabular}

\begin{tabular}{|c|c|}
\hline ARTICLE INFO & ABSTRACT \\
\hline $\begin{array}{l}\text { Keywords: } \\
\text { Vision } \\
\text { BIST Sustainability Index }\end{array}$ & $\begin{array}{l}\text { Purpose - The aim of the study is to determine whether the vision notification concept is } \\
\text { applied in accordance with the purpose of the vision notification concept. The main question of } \\
\text { the study is expressed as "content how many enterprises have the values that should be } \\
\text { included in the vision statement within the vision statements?" }\end{array}$ \\
\hline Received 14 November 2018 & $\begin{array}{l}\text { Design/methodology/approach - In the BIST Sustainability Index, the content of the } 50 \\
\text { companies included in the } 2018 \text { Sustainability Index on their own web sites were analyzed } \\
\text { through a content analysis. }\end{array}$ \\
\hline $\begin{array}{l}\text { Revised } 16 \text { February } 2019 \\
\text { Accepted } 20 \text { February } 2019\end{array}$ & $\begin{array}{l}\text { Results - In the analyzes, it was seen that the number of enterprises which have at least } 4 \text { of the } \\
7 \text { items taken as the benchmarking criteria is } 40 \text { and that all } 50 \text { firms have a vision statement. } \\
\text { This number shows that businesses attach importance to vision. }\end{array}$ \\
\hline $\begin{array}{l}\text { Article Classification: } \\
\text { Research Article }\end{array}$ & $\begin{array}{l}\text { Discussion - Businesses should use their strategic management values in order to turn away } \\
\text { from their competitive environment and turn into a long-lasting structure. The vision statement } \\
\text { contained within these values is of great importance as a future-oriented value. It is seen that } \\
\text { most of the companies analyzed in the study attach great importance to vision. }\end{array}$ \\
\hline
\end{tabular}

\section{Giriş}

Bugünün rekabetçi piyasalarında stratejik yönetim ilkelerine uygun çalışmalar yapan işletmeler büyük birer rekabet avantajı kazanarak rakiplerine karşı daha önde bir pozisyon sahibi olabilmektedirler. İşletmeler örgüt felsefelerini stratejik yönetim felsefesine uygun dizayn ederek avantajlar sağlamaktadır. Stratejik yönetim felsefesinin en önemli değerlerinden biri olan vizyon ifadesi de işletmenin iç ve dış paydaşlarına karşı uyguladığı stratejik felsefenin bir yansıması olarak değerlendirilmektedir. Bu sebeple vizyon ifadesi önemini koruyan ve işletmelere değer katan bir yapı olarak kabul edilebilir.

\section{Önerilen Atıf/Suggested Citation:}

Acar, S. (2019). İşletmelerin Vizyon Bildirimlerinin Stratejik Yönden İncelenmesi: BİST Sürdürülebilirlik Endeksinde Yer Alan Firmalara Yönelik Bir İçerik Analizi, İşletme Araştırmaları Dergisi, 11 (1), 202-215. 
Başarılı işletmelere bakıldığında genellikle vizyon ifadelerine çok büyük önem verdikleri ve vizyon ifadesi ile gelecekte daha da büyüyecekleri anlaşılmaktadır (Ülgen \& Mirze, İşletmelerde Stratejik Yönetim, 2013, s. 177). Bu çalışmada da başarılı olmak için stratejiler belirleyen işletmelere vizyon bildirimi konusunda önemli bilgiler verilmesi amaçlanmaktadır. Bu çerçevede özel bir seçim yöntemiyle endeks içerisine dahil edilen BİST Sürdürülebilirlik Endeksi üyelerinin sahip oldukları vizyon ifadeleri içerik yönünden incelenecektir. Çalışmada yapılan içerik analizine ait sonuçlar bulgular kısmında ve sonuç kısmında incelenecek ve elde edilen değerler sıralanacaktır.

\section{İşletmenin Vizyonu}

Stratejik yönetimin en önemli unsurlarından birini oluşturan vizyon ifadesi işletmeler için hayati önemde bir yer tutmaktadır. Son dönemlerde gelişen teknoloji ile aynı oranda gelişim gösteren yönetimdeki farklılıklar, bugünün örgütlerinin hedeflerinin gerçekleştirilebilmesi ve sürdürülebilir bir gelişim gösterebilmesi için vizyon ihtiyacını ortaya koymuştur (Kılıç, Eren, \& Gürsoy, 2014, p. 37). Vizyon kelimesinin anlamı incelendiğinde, çok farklı tanımlara ulaşılabilmektedir. Ülgen ve Mirze (2013) vizyon ifadesini; "kişilerin ve kurumların, kendilerinin veya işletmelerinin gelecekte olmasını arzu ettikleri durumun ifadesidir." olarak belirtmektedirler. Burada işletmenin gelecekte kendisini nerede göreceğini hayal etmesi olarak kabul edilebilir (Ülgen \& Mirze, 2013, s. 177). Kılıç (2010)'a göre vizyon, "gelecekte ne olmak istediğinin" bir ifadesi olarak kabul edilmiştir (Kılıç, 2010, s. 89). Karaman (2005) vizyon kavramını, "geleceğin nasıl olabileceği ve nasıl olması gerektiğini gösteren bir resim gibi, mevcut gerçeklerin, umutların, hayallerin, tehlikelerin ve fırsatların bir araya gelmesi ile oluşan geleceğin tanımlanması için gerekli zihni bir bakış açısıdır." olarak ifade etmektedir (Özer, 2010, p. 5). Türk Dil Kurumu büyük sözlüğünde ise "görünüm, ülkü, sağgörü ve ileri görüss" olarak tanımlanmaktadır (Türk Dil Kurumu, 2018). İşletmeler vizyon ifadesi ile geleceği daha net görmeyi hedefleyerek aynı zamanda çalışanları ile sıkı bağlar kurabilirler (Muslu, 2014, p. 163). Vizyon ifadesi, görüş anlayış ve kavrayış olarak tarif edilebilir. Aynı zamanda vizyon ifadesi tanımlarına, uyanık olmakta ilave edilebilmektedir (Önen, 2017, p. 3). Vizyon bildirimi işletmenin nereye gitmek istediğini belirten unsurdur (Ocak, Güler, \& Basım, 2016, p. 504). Vizyonu işletmenin ortak hedefleri ve inançlarını ifade edecek biçimde oluşturulan geleceğe yönelik zihni bir imaj olarak yorumlamak mümkündür. Aynı zamanda vizyon, işletmenin temel ve ortak değerleri ekseninde geliştirilen uygulama biçimi, stratejilerin biçimlenmesi konusunda yardımlarda bulunan bir çerçeve ve yol gösteren bir ifade olarak kabul edilebilir (Tatlı \& Üstün, 2018, p. 20).

Vizyon diğer bir stratejik unsur olan misyon gibi işletme için stratejik yönetim sürecinde çok önemli ve bazı yazarlara göre (Ülgen \& Mirze, 2013, s. 179; Dinler, 2009, s. 3) tek başlangıç noktasıdır. İşletmelerin gitmek istedikleri yeri bildirdikleri ifade vizyon ifadesidir. İşletmeler, vizyona ulaşabilmek için belirledikleri duygu ve değerlerin 1şığında oluşturdukları eylem planlarını kullanırlar (Ülgen \& Mirze, 2013, s. 177). Vizyonun bir başka anlamı olan "gerçekleştirilebilir amaç" anlamı doğrultusunda her işletmenin yazılı olan ya da yazılı olmayan bir vizyonu vardır. Vizyon kavramı işletmenin ne olduğu konusunda tanımlamalar yapar, işletme kimliğinin odak noktasında yer alır, işletmenin sahip olduğu yetenekleri, kaynakları ve kapasitesinin ne olduğunu ifade eder. Aynı zamanda ne amaçla kurulduğu konusunda bilgi verirken, geldiği yeri ve gideceği yeri de göstermektedir. Ancak vizyon gidilecek yeri ifade ederken o yoldaki uygulama süreçlerini ifade etmemektedir (Lamba, 2014, p. 85). Vizyon oluşturma faaliyeti, sadece işletme stratejisinin ana hatlarını oluşturur, diğer detaylar ise sürece bırakılır (Ocak, Güler, \& Basım, 2016, p. 504).

\section{İşletmelerde Vizyonun Önemi ve Gereği}

İşletmeler için vizyon bildirimi dönüşüm sürecinin başladığı noktayı ifade ederken, aynı zamanda örgütün ileride olmak istediği şeyin resmedilmiş hali olarak kabul edilebilir. Bütün örgütler aslında eski tecrübelerinden faydalanarak ne yapılmasının gerektiği ve istendiğini belirlemeden hayatlarına başlamamaktadırlar. Bir örgüt için vizyon ifadesi, strateji, hedeflerin belirlenmesi ve örgütün gelecekte ne olacağını belirlemesi yönleriyle yöneticilere yol gösteren bir yapıya sahiptir. Vizyonun bir diğer önemli özelliği de yıllar geçerken günün şartlarına göre değişim göstermek yerine ilk oluşturulduğu günkü özünü asla kaybetmeden kalıcı bir yapı oluşturmasıdır. Bu sebeple herhangi bir değişim ihtiyacı olmadığı sürece değiştirmeden aynı hedefe doğru yürünmesinde fayda vardır (Ocak, Güler, \& Basım, 2016, p. 505). Bu yönüyle vizyon, örgütün gelecekte sağlayacağı başarılarına ulaşabilmesi için oluşturulmuş bir amaçlar topluluğu ve bir yol haritası ya da rota niteliği taşımaktadır. Bu sebeple vizyon oluşturulurken, örgütün 
sahip olacağı performansını ve geleceğe yönelik hedeflerini yükseltecek biçimde oluşturularak örgütün değişime olan isteğini artırıcı bir katkıda bulunmalıdır. Yine aynı bakış açısıyla sabitlenmiş bir takım tutumlardan ve tahminlerde bulunmaktan ziyade gelecek için kararlar alma sürecidir (K1lıç, Eren, \& Gürsoy, 2014, p. 46).

Bir işletmede bütün üyelerin benimsediği bir vizyon çalışanları birbirine bağlar. Bu ortak vizyon sayesinde, üyeler arasında amaç birliği oluşur. İnsanlar yapıları gereği kendilerinden daha büyük bir yapının üyesi olmak isterler. Ortak bir vizyon bu ihtiyacı karşılayarak üyelere ortak bir amaç kazandırır. İşletmede yer alan üyelere ortak amaçlar vererek enerjilerinin işletme faydasına yöneltilmesine katkı sağlamaktadır (George, 1997, s. 66).

İşletmenin belirlediği hedeflere yönelmesine yardımcı bir araç olarak vizyon işletmenin içerisine düşeceği beklenmedik durumlarda ya da belirsizlik durumlarında işletmenin hangi yollara doğru yöneleceğine dair yönelimlerde de bulunabilecektir. Bu özellik işletmenin diğer işletmelerden kendini ayıran bir farklılık olarak kabul edilmelidir. Ayrıca geleceğe yönelik faaliyetlerde işletmenin çalışanlarına bir rehber niteliği taşır. Çalışanlar vizyon sayesinde işletmenin hedeflerini öğrenerek o yöne doğru çalışmalarda bulunur. Bir işletmede vizyon varsa başarıya, işbirliğine, rasyonel davranışa ve yenilikçiliğe doğru yol alan bir yapı sergiler. Eğer vizyon yoksa başarısızlık, yeteneksizlik gibi olumsuzluklar çerçevesinde işletme bir kaos içerisine sürüklenir (Ülgen \& Mirze, 2013, s. 178). George (1997)'un verdiği bilgilere göre, bir işletmenin vizyonu işletmenin tüm üyeleri tarafından benimsenmiş ise yapılan iş daha mükemmel olmaktadır. Bu sayede bütün çalışanlar için karşılıklı bir faydalanma imkanı oluşturulmuş olur. Aynı zamanda işletmenin hedefleri ile çalışanların hedefleri ortak bir hal almaktadır (George, 1997, s. 66).

Vizyon bildirimi, işletmelerin yöneticilerine motivasyon sağlayan ve işletmeye de yön veren çok önemli bir değerdir. Vizyon ifadesinin başarılı olabilmesi için nicel hedefler içermeli ve ulaşılabilir bir yapıda olmalıdır. Bu sayede işletmenin amaçları bütün üyelere aktarılarak ortak bir amaç haline getirilebilir (İnce, 2015, s. 146).

Vizyonun başarılı olabilmesinde büyük etkiye sahip olan unsur bir lider ya da örgütün üst yönetimidir. Yönetimin örgütün diğer üyelerine vizyon bildirimini benimsetmesi vizyonun başarısını etkiler. Teorikte vizyonun bütün örgüt üyeleri tarafından paylaşıldığı düşünülse bile uygulamada örgütün yazılı bir vizyonu olsa bile üyelerin vizyonu paylaşmadıkları ve uygulamalarında bu vizyona göre davranışlar sergilemedikleri görülmektedir. Bu durumun yaşanmaması için vizyon oluşturulurken sadece üst düzey yöneticiler ve birkaç kişilik uygulama gruplarının katılımı yerine bütün örgüt üyelerinin vizyon oluşturma sürecine katılımı özendirilmeli ve katılımları sağlanmalıdır. Kaliteli bir vizyon örgüt üyelerinin, örgütte bulunan grupların ve tümüyle örgütün başarısı için çalışan ve örgütün hangi yönlerde gelişme göstereceğini paydaşlara yansıtan bir yapıda olmalıdır. Bu birliktelik sağlandığında üyelerin vizyona olan bağlılıkları daha yüksek olacaktır (Ülgen \& Mirze, 2013, s. 178). Vizyon bildirimi bu sayede hem işletmenin hedeflerini ve gelecekte olacağı konumu belirlerken hem de paydaşların işletmeye karşı tutumlarını ve bakış açılarını ortaya çıartan göstergelerden olma konumuna gelmektedir. Tam tersine vizyon bildirimi olmayan bir örgütün hangi yöne gideceğini ve sonuçta hangi noktaya ulaşacağını belirleyebilmek zor bir durumdur (Ateş, 2016, p. 404).

Vizyon bildirimi ile örgütlerde etkili bir yönetim oluşturma imkanı doğmaktadır. Etkili liderler için vizyonun büyük önemi bulunmaktadır. Bu önem işletmeye faydalar sağlar. Vizyonun işletmeye oluşturduğu faydalar şu şekilde belirtilmektedir (George, 1997, s. 66):

- İşletmedeki bütün çalışanlar bağlayııı bir etki oluşturur.

- İşletmenin yaptığı operasyonların basitleşmesini sağlar.

- İşletme faaliyetlerinin kıyaslanmasına imkan tanır.

- İşletmenin faaliyetlerine odaklanarak daha etkili faaliyetlerde bulunmalarına katkı sağlar.

\section{Vizyonun Türleri}

Örgütler vizyon bildirimlerini iki ana hedefe yönelik hazırlayabilirler. Bunlardan birincisi içinde bulunulan döneme ilişkin olarak hazırlanan mevcut vizyonu, ikinci olarak ise gelecek dönemlerde işletmenin karşılaşacaklarına yönelik olarak gelecek vizyonu olmaktadır. Mevcut dönem vizyonu örgütün içinde bulunduğu yeri göstermek amacıyla hazırlanır. Vizyon gelişiminin hangi noktadan başladığı mevcut vizyona bakılarak net bir biçimde görülebilir. Gelecek vizyonu ise daha çok örgütün ulaşmak istediği 
noktayı belirlemesi amacıyla belirlenmelidir. Gelecek vizyonu ve mevcut vizyonu olmayan örgütlerin mevcut konumlarından geleceğe doğru ilerlemeleri zor olacaktır. Bu süreçte başarı isteniyorsa mevcut vizyon ve gelecek vizyonu belirlenmelidir (Ülgen \& Mirze, 2013, s. 179).

Collins ve Porras (1996) bu ayrımı farklı bir biçimde isimlendirerek, temel ideoloji ve vizyonlaştırılmış gelecek olarak kabul etmişlerdir. Temel ideoloji, örgütün neden var olduğunu ifade eder ve neyi temsil ettiği ile ilgili bilgiler verir. Büyük örgütler temel ideolojilerini ortaya koyarak bir başlangıç noktası belirlemişlerdir (Collins \& Porras, 1996). Örgütün temel ideolojiye bağlı vizyonu, örgütün amaçları ve temel değerleri etrafında şekillenir ve "biz kimiz?", "neden varız?" ve "neyi temsil ediyoruz?" gibi sorulara verilen cevaplardan oluşur. Vizyonlaştırılmış gelecek ise örgütün gelecekte hangi noktada bulunmak istediğine odaklanan yön olarak ifade edilmektedir. Bugünden belli olamayan fakat amaç ve hedefler doğrultusunda hangi noktada bulunulacağı konusu bu alanda işlenir. Burada oluşturulan hedef örgüt üyelerinin de birleşmelerine ve aynı hedefe odaklanmalarına destek olacak niteliktedir (Kılıç, 2010, s.90).

Joseph V. Quigley (1998) vizyon bildirimi konusunda, üç unsurun gerçekleşmesi gerektiği üzerinde durmaktadır. Öncelikle örgütün değerlerini tespit etmek gerekmektedir. Ardından örgüt misyonu ve hedeflerini belirlemek ile devam edilir. Üçüncü unsurda ise örgütün hedefleri netleştirilerek süreç tamamlanır (Akgemci, Çelik, \& Ertuğrul, 2004, p. 3).

\section{Vizyonun Unsurları}

Örgütün belirlediği vizyon bildiriminin güçlü, anlaşılır, net ve ilham verici olması gereklidir. Vizyon yazılırken herkesin anlayabileceği şekilde yazılmalıdır. Okuyan herkesin aynı anlamı çıartması ve örgüt üyelerini doğru yöne yönlendirmesi gereklidir. Vizyon ifadesinin mümkün olduğu kadar kısa hazırlanması gerekir ancak daha uzun vizyonlarda olabilmektedir. Vizyon işletmenin farklılaşan bütün bölümlerine hitap etmeli ve onları heyecanlandırmalıdır. Hazırlanmış olan vizyon ifadeleri üyeler arasında tartışmalara yol açmayacak şekilde net, basit ve anlaşılır olmalıdır. Örgütün hedeflerini, önceliklerini ve amaçlarını içermelidir (Alkoç, 2010, pp. 35-41). Ancak yine de bir örgütün geleceğe yönelmesinde vizyon tek başına yeterli olamamaktadır. Bir örgütün vizyonu; örgütün amaç, hedef, değer ve misyonunun bir bileşimidir. Bu durum Şekil.1'de aktarılmaktadır (Ülgen \& Mirze, 2013, s. 181,182):

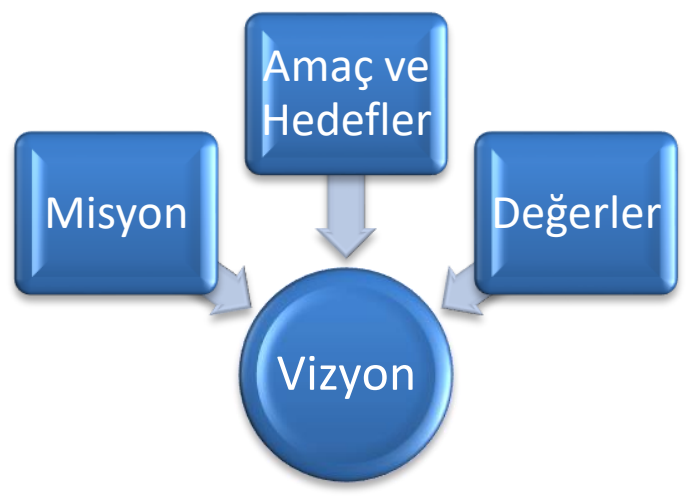

Şekil.1: Vizyonun Unsurları Kaynak: (Ülgen \& Mirze, 2013, s. 182)

Vizyon ifadesi misyon, değer ve hedeflerin yanında bir değer daha içermelidir. Bu ifade imajdır. İmaj kavramı, gelecekte olması çok istenen bir durumun veya amaç ya da değerimizin gerçekleştiğinde nerede olacağımızı ifade eden kavramdır. Bu yapı kişisel ve kurumsal olarak ayrılan değerlerin bir parçası olabileceği gibi tamamlayıcısı da olabilmektedir (Ülgen \& Mirze, 2013, s. 182).

Vizyon bildirimlerinin özünde neleri içerdiğine bakıldıktan sonra biçimsel olarak nasıl bir yapı oluşturması gerektiği de önem kazanmaktadır. Özellikle son dönemde oluşan işletmeler arasındaki rekabet sonrasında bir vizyonun hangi değerleri barındırması gerektiği büyük önem kazanmaktadır. Akgemci ve Güleş (2009)'e göre bir vizyon ifadesi aşağıdaki değerleri barındırmalıdır (Akgemci \& Güleş, 2009, p. 14);

- İdealisttir; yürekten gelmesi, hissedilmesi gerekir.

- Özgündür; örgüte aidiyeti belirgindir.

- Ayırt edicidir; örgütün vizyonunu diğerlerinden ayırt edici özelliğe sahiptir. 
- Çekicidir; örgütün içinden olan ve olmayan kişilerin ilgisini çeker.

- Kisa ve akılda kalıcidir.

- İlham verici ve iddialıdır.

- Gelecekteki başarıları ve ideal olanı tanımlayıcıdır.

$\mathrm{Bu}$ listenin haricinde bir çok araştırmacı vizyon ifadesinin içeriğine ilişkin farklı önerilerde bulunmuştur. Bu önerilerin ayrıntılı bir biçimde ifade edilişi Tablo 1'de sunulmaktadır.

Tablo 1: Vizyon Bildiriminde Yer Alması Gereken Değerler

\begin{tabular}{|c|c|}
\hline Yazar & Vizyon İçeriği \\
\hline Collins ve Porras (1996) & Öz değerler, öz amaçlar, büyük hedefler. \\
\hline Alcorn (1998) & Öz değerler, öz amaçlar, büyük hedefler. \\
\hline Abelman ve Amy (2008) & $\begin{array}{l}\text { Paylaşılmışlık, açıklık, zorlayıcılık, karmaşıklık, avantaj sağlayıcılık, } \\
\text { gözlemlenebilirlik. }\end{array}$ \\
\hline $\begin{array}{l}\text { Brătianu ve Bălănescu } \\
\text { (2008) }\end{array}$ & Varlık nedeni, temel değerler, sosyal sorumluluk, edebîlik, anlamlılık. \\
\hline Kasowski ve Filion (2010) & $\begin{array}{l}\text { Gelecek yönelimlilik, pazar odaklılık, netlik ve gerçekleştirilebilirlik, } \\
\text { değişim odaklılık. }\end{array}$ \\
\hline Yozgat ve Karataş (2011) & Sosyal sorumluluk, çevresel duyarlılık, etik davranışlar \\
\hline Burke (2011) & $\begin{array}{l}\text { Kısalık, açıklık, somutluk ve meydan okuyuculuk, hedefler, gelecek } \\
\text { yönelimlilik, arzu edilen amaçlar, başarı kriterleri. }\end{array}$ \\
\hline Masood vd. (2012) & $\begin{array}{l}\text { Kısalık, açıklık, somutluk, yaratıcılık, ilham vericilik, öz olmak, güven } \\
\text { vericilik, fırsatları tanımlayıcılık, gelecek yönelimlilik, eylem odaklılık, } \\
\text { uzun dönemlilik, esneklik. }\end{array}$ \\
\hline Ay ve Koca (2012) & $\begin{array}{l}\text { Liderlik, yenilikçilik, küresellik, büyüme-gelişme, öncülük, kalite, } \\
\text { sosyal sorumluluk, ekonomiklik. }\end{array}$ \\
\hline Haghighi vd. (2013) & $\begin{array}{l}\text { Kısalık, açıklık ve anlaşılabilirlik, gelecek yönelimlilik, değişim } \\
\text { odaklılık, ilham vericilik, arzu dolu olmak, net hedefler. }\end{array}$ \\
\hline Papulova (2014) & $\begin{array}{l}\text { Anlaşılabilirlik, hatırlanabilirlik, olumluluk, motive edicilik, ilham } \\
\text { vericilik, cezbedicilik, meydan okuyuculuk, gelecek yönelimlilik. }\end{array}$ \\
\hline
\end{tabular}

Kaynak: (Ocak, Güler, \& Basım, 2016, p. 506)

Araştırmacıların vizyon ifadesinde bulunan değerlerin hepsini farklı yönlerden değerlendirdikleri görülmektedir.

Belirtilen şartları sağlayan vizyon ifadeleri genellikle kabul görmektedir ve işletmenin hedefine doğru yürümesinde büyük katkılar sağlamaktadır. Ancak bu çalışmada Akgemci ve Güleş (2009)'in belirttiği şartlar vizyon ifadeleri içerisinde aranacak ve bu ifadeleri beyan eden vizyon ifadeleri belirlenecektir. Analize tabi tutulacak olan vizyon ifadeleri idealist olma, özgün olma, ayırt edici olma, çekici olma, kısa ve akılda kalıcı olma, ilham verici ve iddialı olma ve gelecekteki başarı ve idealleri olma yönlerinden incelenecek ve sonuçta bu grupların hangisi ya da hangilerine dahil edilmesi gerektiğine karar verilecektir.

\section{Vizyon İle Strateji İlişkisi}

Strateji, çevrede yer alan rakip işletmelerin yapabileceği adımları önceden tahmin ederek, işletmenin hedefleri odaklı ve nihai amaçların doğrultusunda uzun dönemli ve dinamik olarak verilmiş olan kararlar 
topluluğudur. İşletmeler stratejilerini oluştururken misyon ve vizyon bildirimlerini dikkate alarak faaliyetlerine başlarlar (Alkoç, 2010, p. 45). Ülgen ve Mirze (2013)'e göre strateji kısaca "plan" anlamına gelmektedir. Stratejinin, plan olarak tanımlanmasının sebebi ise stratejide temel hedefin örgütün arzuladığı ve istediği sonuçlara ulaşmayı beklemesidir. Bu yönüyle planlara çok benzemektedir (Ülgen \& Mirze, 2013, s. 35).

Vizyon ile strateji örgütün gelecek ile ilgili iki değeri olarak kabul edilebilir. Strateji ile vizyon arasında hiyerarşik olarak bir bağ bulunmaktadır. Bu bağ sayesinde stratejiler uygulanarak vizyona ulaşılma adımları tayin edilebilir. Strateji geleceğe yönelik yapılacak adımlarda araç ve gerekli değerleri de belirler ancak vizyon bu belirlemeyi gerçekleştiremez (Muslu, 2014, p. 166). İşletmelerin belirledikleri stratejilerin başlangıç noktası çoğu zaman vizyon bildirimi olmaktadır. Bu yönüyle vizyon stratejiye yol gösteren bir pusula gibidir (Alkoç, 2010, p. 46).

Strateji ile vizyon arasındaki ilişki stratejik yönetimin de vizyon çerçevesinde gelişmesine yol açacaktır. Stratejik yönetim Ülgen ve Mirze (2013)'e göre “işletmenin uzun dönemde yaşamının devam ettirilmesine ve sürdürülebilir rekabet üstünlüğü sağlamasına yönelik bilgi toplama, analiz, seçim, karar ve uygulama faaliyetlerinin tümü" olarak ifade edilmektedir. Bu nedenle stratejik yönetim bir kerelik kararlardan ziyade süreç ifade eden ve sürdürülebilir kararlardan oluşmaktadır. Bir süreç olarak düşünülmeden oluşturulan stratejileri temel alan uygulamalar işletmeyi başarısızlığa götürecektir (Ülgen \& Mirze, 2013, s. 33). Ayrıca stratejik yönetimin temel amacı işletmeleri belirlenen vizyona doğru yönelterek o yönde gelişim göstermelerine yardım edecektir. Bu noktada vizyonun stratejik yönetime en büyük katkısı işletmenin amaç ve hedeflerinin belirlenmesinde yol gösterici kimliğidir. Vizyonun yol göstericiliği strateji üretenlere belirli sınırlar koyarak başka yönlere yönelmelerinin önüne geçerek hedefe doğru yol almalarını sağlar. Ayrıca vizyon yöneticiler üzerinde motive edici bir etki bırakır. Yöneticiler, bunun yanında işletme vizyonunun bütün işletme üyeleri tarafından benimsenmesine büyük önem vermelidirler. İnanılan bir vizyon işletmeyi başarıya götürecektir (Doğan \& Hatipoğlu, 2009, pp. 90,91).

\section{Literatür Taraması}

Literatürde işletmelerin vizyon ifadelerinin önemi ve anlamı ile ilgili yer alan çalışmalardan bazıları burada belirtilmektedir.

Tatlı ve Üstün (2018), BİST 100 endeksindeki firmalara yönelik olarak yapıtkları araştırmada, işletmelerin vizyon, misyon, örgütsel değer ve staratejik amaçlarına yönelik bir içerik analizi uygulamışlardır. Bu analiz sonuçlarına göre işletme vizyonlarında liderlik ve yenilikçilik kavramları doğrultusunda, gelişen dünya ekonomisine karşı sürdürülebilirlik ve küreselleşme kavramlarının ön plana çıkarıldığı görülmektedir (Tatlı \& Üstün, 2018).

Erden Ayhün ve Çavuşgil Köse (2018) yapmış oldukları araştırmada, Türkiye'deki yiyecek-içecek işletmelerini incelemişlerdir. Bu araştırmada, fast-food sektöründe yer alan 10 yiyecek-içecek işletmesinin misyon ifadeleri, Pearce ve David (1987) tarafından belirlenmiş olan kriterler çerçevesinde ve vizyon ifadeleri ise Kantabutra (2008) tarafından belirlenen kriterler çerçevesinde incelenmiştir. Yapılan içerik analizi sonucunda araştırmaya tabi tutulan işletmelerin misyon ifadelerinde eksikleri bulunduğu, vizyon ifadelerinde ise bütün şartları karşıladıkları sonucuna ulaşılmıştır (Erden Ayhün \& Çavuşgil Köse, 2018).

Latif ve Muslu (2015), yaptıkları araştırmada misyon ve vizyon ifadelerindeki anlam kargaşasını ön plana çıkartmışlardır. Yapılan araştırmada misyon ifadelerinde Pearce ve David (1987) tarafından belirlenen 10 kriter, vizyon ifadeleri için ise Akgemci ve Güler (2009) tarafından belirlenmiş olan 7 kriter inceleme konusu olmuştur. Elde edilen sonuçlara göre, incelemeye alınan 100 işletmeden 41 tanesinde misyon ifadesinin olmaması, 38 tanesinde ise vizyon ifadesinin olmaması işletmelerin misyon ve vizyon ifadelerine gereken önemi göstermediklerini ortaya koymuştur. İncelemeler sonucunda işletmeler vizyon ifadelerinde, idealist olma, özgün olma, ayırt edici olma, çekici olma, iletişim, gelecek tanımlayıcı olma ve ilham verici olma unsurlarını sıklıkla kullanmışlardır (Latif \& Muslu, 2015).

İnce (2015), yapmış olduğu araştırmada Türkiye'nin ikinci 500 büyük şirketinden ulaşılabilen 305 şirketin misyon ve vizyon ifadelerini girişimcilik bağlamında incelemiştir. Çalışmanın ulaştığı sonuçlara göre, vizyon ifadelerinde; başarı, liderlik, yenilikçilik ve rekabetçilik vurguları ön plana çıkmış olarak bulunmuştur (İnce, 2015). 
Güney (2015), BİST 100 endeksinde yer alan işletmelerin misyon ve vizyon ifadelerine yönelik yaptığ1 araştırmasında çevre ilişkisini incelemiştir. Bu araştırma kapsamında misyon ifadelerinde çevre ile ilgili bilgilere yer veren işletme sayısı 14 iken vizyon ifadelerinde çevre ile ilgili bilgilere yer veren işletme sayısının ise 5 olduğu görülmüştür. Vizyon ifadesinde çevre ile ilgili bilgilere yer veren işletmelerin 4 tanesinin imalat sanayisinde yer alması ve 1 tanesinin de mali kuruluş olması dikkat çekicidir (Güney, 2015).

Doğan ve Hatipoğlu (2009), vizyon ifadesi ile işletme performansı arasındaki ilişkiye yönelik bir araştırma yapmışlardır. Bu araştırmada küçük ve orta boy işletme niteliğindeki iki işletme ele alınmıştır. Bir işletme internet sitesinde vizyon bildirimi yapmakta iken diğer işletme ise vizyon bildirimi yapmamaktadır. Bu iki işletmenin arasındaki performans farklılığı çalışmanın temelini oluşturmaktadır. Bu kapsamda işletmelerin, 2004, 2005, 2006 ve 2007 yıllarındaki mali bilanço ve gelir tabloları değerleri ile yıllık çalışan sayıları incelenmiştir. Yapılan incelemeler sonucunda vizyon ifadesi açıklamanın işletme performansına olumlu katkılarda bulunduğu ifade edilmiştir (Doğan \& Hatipoğlu, 2009).

\section{Araştırmanın Amacı}

Çalışmanın çıkış noktası, işletmelerin belirledikleri vizyon ifadelerinin, literatürde daha önceden oluşturulan ideal karakteristik özelliklere ne derece sahip olduklarıdır. Bu çerçevede araştırmanın amacı; BíST Sürdürülebilirlik Endeksinde yer alan firmaların belirledikleri vizyon ifadelerinin olması gereken ideal özellikleri barındırma seviyelerini tespit etmektir. Vizyon ifadelerinde yer alan noktalar belirlenerek eksiklikler belirlenmeye çalışılacaktır.

\section{Araştırmanın Yöntemi}

Araştırmada nitel analiz yöntemleri kullanılmaktadır. İslamoğlu (2011)'na göre nitel araştırmalar; "sosyal olguları bağlı oldukları ve içinde yer aldıkları ortamda doğal görünümleriyle gözlem, görüşme ya da belgeleri değerlendirmek yoluyla bilgi edinme ve bu bilgileri analiz ederek kuram geliştirme" olarak tanımlanmaktadır. Nitel araştırmalar olayları hep aynı gözle gören ve değerlendiren nicel araştırmalara göre çok daha dinamik bakış açısı imkanı vermektedir. Nitel araştırmalar verilere doğal bir yapı içerisinde ve kendi bütünlügü ile bakarak oluşan örüntüleri, farklılıkları ve tekrarlanan sıklık değerlerini inceleyerek yasalar ve kuramlar geliştirmeyi sağlar (İslamoğlu, 2011, p. 186).

Araştırmada ikincil veriler kullanılmaktadır. Veriler araştırma kapsamına giren işletmelerin kendilerine ait olan internet sitelerinde yer alan vizyon ifadelerinden oluşmaktadır. Bu ifadeler nitel analiz yöntemlerinden içerik analizi yöntemi ile analiz edilmiştir. Akgemci ve Güleş (2009)'in vizyon ifadelerinde olması gereken bileşenler listesine göre bir değerlendirme yapılarak vizyon ifadelerinden bu bileşenlerden olanlar için (+) olmayanlar için (-) sembolleri ile kodlaması yapılmış ve bu elde edilen veriler ışığında içerik analizi uygulanmış ve bulgular elde edilmiştir. Vizyon bildirimleri Akgemci ve Güleş'in belirttiği 7 ayrı bileşeni ayrışık olarak kategori haline getirilerek değerlendirme sürecine alınmıştır. 7 bileşen; idealist olma, özgün olma, ayırt edici olma, çekici olma, kısa ve akılda kalıcı olma, ilham verici ve iddialı olma ve gelecekteki başarı ve idealleri olma olarak kategori haline getirilmiştir. Belirlenmiş olan 7 bileşene ulaşabilmek adına 7 ayrı soru belirlenerek bu sorulara cevaplar aranmıştır. Bu sorular (Latif \& Muslu, 2015, p. 18);

- İdealist: İşletmenin temel amaç ve hedefleri var mıdır?

- Özgünlük: İşletme, kendine özgü değerlere sahip midir?

- Ayırt edicilik: İşletme vizyonu, ayırt edici özelliğe sahip midir?

- Çekicilik: İşletme iç ve dış ortaklarının ilgisini çekmekte midir?

- Kısa ve Akılda Kalıcılık: İşletme, vizyonunu tüm paydaşlarına iletebiliyor mu?

- İlham verici ve İddialılık: İşletme çalışanlarına ilham vermekte midir?

- Gelecekteki Başarı ve İdealler: İşletmenin tasarlanmış bir gelecek planı var mıdır?

Çalışmada kullanılan yöntem olan içerik analizi, Kurtuluş (2010)'a göre, 'içeriğin oluşumunda araştırmacının etkisi olmayan materyallerin içeriğine ilişkin objektif bir değerlendirme şekli geliştirmeyi amaçlayan' bir model olarak kabul edilmiştir. İçerik analizindeki temel amaç içerik içerisine gizlenmiş ve ilk bakışta görülmeyen gizli değerleri oraya çıkarmaktır (Kurtuluş, 2010, pp. 50,51). 


\section{Araştırmanın Evreni}

Araştırma, BIST Sürdürülebilirlik Endeksinde 2018-2019 yılları arasındaki dönemde yer alan 50 firma üzerinde uygulanmıştır. Araştırmanın evrenini bu 50 işletme oluşturmaktadır. Araştırmanın örneklemini ise bu firmalar arasından internet sitelerinde ve sürdürülebilirlik raporlarında vizyon bildirimi yapmış olan firmalar oluşturmaktadır. Yapılan inceleme sonucunda 50 firmanın hepsinin vizyon ifadelerine yer verdiği ve vizyon bildirimi olmayan hiçbir firmanın olmadığı tespit edilmiş ve bu sebeple bütün firmalar araştırmaya tabi tutulmuştur.

\section{Araştırmanın Kısıtları}

Araştırmaya BİST Sürdürülebilirlik Endeksinde yer alan 50 firma harici bir firmanın dahil edilmemesi ve bir kıyaslama imkanının oluşturulamaması büyük bir kısıt olarak kabul edilebilir. Ayrıca vizyon bildirimlerinin sadece internet sitelerinden alınması ve mülakat vb. gibi diğer nitel araştırma yöntemleriyle desteklenmemesi de ikinci bir kısıt olarak kabul edilebilir. İleriki çalışmalarda bu konu dikkate alınarak daha geniş kapsamlı bir çalışma gerçekleştirilebilir. Bu kısıtların göz önüne alınması ile daha net sonuçlara ulaşılması mümkün olacaktır.

\section{Araştırmanın Güvenilirliği}

Araştırma kapsamına alınan 50 firmanın vizyon ifadeleri öncelikle nitel araştırmalar konusunda çalışan tarafsız iki araştırmacıya yönlendirilerek Akgemci ve Güleş (2009)'in 7 ana bileşimi ile ilgili olarak hangi değerleri içerdiğine yönelik inceleme yapmaları istenmiştir. Daha sonra araştırmacılar değerlendirmelerini yaparak tutarlılık düzeyi kontrol edilmek üzere incelemeye alınmıştır. Araştırmacıların verdikleri bilgiler kapsamında Holsti (1969)'nin nominal verinin güvenilirliğini hesap ettiği "Güvenilirlik = 2M (N1+N2)" formülü esas alınarak elde edilen sonuçlar kıyaslanmış ve hesaplanmış elde edilen oran \%88 düzeyinde belirlenmiş ve $\% 88$ oranında tutarlı olduğu sonucuna varılmıştır.

\section{Bulgular}

Araştırma çerçevesi içerisinde 2018 yılında BİST Sürdürülebilirlik Endeksinde yer alan 50 firmanın internet siteleri ve Sürdürülebilirlik Raporlarında ifade ettikleri vizyon bildirimleri, vizyon ifadelerinde olması beklenen 7 bileşen yönünden analize tabi tutulmuş ve elde edilen veriler kategori haline getirilerek bu bölümde ortaya konmuştur. Araştırmaya dahil edilen 50 firmanın vizyon bileşenleri ile ilgili verileri Tablo 2'de ifade edilmektedir.

Tablo 2: BİST Sürdürülebilirlik Endeksinde Yer alan Firmaların Vizyon Analizleri

\begin{tabular}{|l|l|c|c|c|c|c|c|c|c|}
\hline & & İdealist & Özgünlük & $\begin{array}{c}\text { Ayırt } \\
\text { Edicilik }\end{array}$ & Çekicilik & Kisalık & $\begin{array}{c}\text { İham } \\
\text { Vericilik }\end{array}$ & $\begin{array}{c}\text { Gelecek } \\
\text { Tanımlayıc }\end{array}$ & TOPLAM \\
\hline 1 & AK ENERJ & - & + & - & - & - & + & + & 3 \\
\hline 2 & AKBANK & + & - & - & - & + & + & + & 4 \\
\hline 3 & AKSA & + & + & - & - & + & - & + & 4 \\
\hline 4 & AKSA ENERJI & + & - & - & - & + & + & + & 4 \\
\hline 5 & $\begin{array}{l}\text { ANADOLU } \\
\text { CAM }\end{array}$ & + & + & + & - & - & - & + & 4 \\
\hline 6 & $\begin{array}{l}\text { ANADOLU } \\
\text { EFES }\end{array}$ & + & - & + & + & + & - & + & 5 \\
\hline 7 & $\begin{array}{l}\text { ANEL } \\
\text { ELEKTRIK }\end{array}$ & - & + & + & - & - & + & - & 3 \\
\hline 8 & ARCELIK & + & + & + & - & + & + & + & 6 \\
\hline 9 & ASELSAN & + & + & + & + & - & + & - & 5 \\
\hline 10 & AYGAZ & + & + & + & - & + & + & + & 6 \\
\hline 11 & BRISA & - & + & - & - & + & + & + & 4 \\
\hline 12 & CIMSA & + & + & + & - & - & - & + & 4 \\
\hline 13 & $\begin{array}{l}\text { COCA COLA } \\
\text { ICECEK }\end{array}$ & + & - & - & - & - & + & + & 3 \\
\hline 14 & DOGAN & + & + & - & - & - & + & + & 4 \\
\hline
\end{tabular}


S. Acar 11/1 (2019) 202-215

\begin{tabular}{|c|c|c|c|c|c|c|c|c|c|}
\hline & HOLDING & & & & & & & & \\
\hline 15 & \begin{tabular}{|l|} 
DOGUS \\
OTOMOTIV
\end{tabular} & + & + & + & - & + & - & + & 5 \\
\hline 16 & \begin{tabular}{|l|} 
EREGLI \\
DEMIR CELIK
\end{tabular} & + & + & - & + & - & + & + & 5 \\
\hline 17 & \begin{tabular}{|l} 
FORD \\
OTOSAN
\end{tabular} & + & + & + & - & - & + & + & 5 \\
\hline 18 & \begin{tabular}{|l|} 
GARANTI \\
BANKASI \\
\end{tabular} & + & + & + & - & + & - & + & 5 \\
\hline 19 & $\begin{array}{l}\text { GLOBAL } \\
\text { YATIRIM } \\
\text { HOL. }\end{array}$ & + & + & - & - & - & + & + & 4 \\
\hline 20 & IS BANKASI & + & + & - & + & - & + & - & 4 \\
\hline 21 & $\begin{array}{l}\text { KOC } \\
\text { HOLDING }\end{array}$ & - & - & + & + & - & - & + & 3 \\
\hline 22 & $\begin{array}{l}\text { KORDSA } \\
\text { GLOBAL }\end{array}$ & + & + & + & - & + & + & + & 6 \\
\hline 23 & \begin{tabular}{|l} 
LOGO \\
YAZILIM
\end{tabular} & + & - & + & - & - & + & + & 4 \\
\hline 24 & $\begin{array}{l}\text { MIGROS } \\
\text { TICARET }\end{array}$ & - & + & - & + & - & + & + & 4 \\
\hline 25 & $\begin{array}{l}\text { NETAS } \\
\text { TELEKOM. }\end{array}$ & - & + & + & - & + & - & + & 4 \\
\hline 26 & OTOKAR & + & + & + & - & - & - & + & 4 \\
\hline 27 & PEGASUS & + & + & + & + & + & + & + & 7 \\
\hline 28 & \begin{tabular}{|l|} 
PETKIM \\
\end{tabular} & + & + & - & + & + & - & - & 4 \\
\hline 29 & $\begin{array}{l}\text { POLISAN } \\
\text { HOLDING }\end{array}$ & - & + & + & + & - & - & + & 4 \\
\hline 30 & $\begin{array}{l}\text { SABANCI } \\
\text { HOLDING }\end{array}$ & - & + & + & + & + & + & + & 6 \\
\hline 31 & ŞEKERBANK & + & + & - & - & + & + & + & 5 \\
\hline 32 & SISE CAM & + & + & + & - & + & + & + & 6 \\
\hline 33 & \begin{tabular}{|l} 
SODA \\
SANAYII
\end{tabular} & - & + & + & - & - & - & + & 3 \\
\hline 34 & \begin{tabular}{|l|l|l|} 
T. HALK \\
BANKASI \\
\end{tabular} & + & + & + & - & - & - & + & 4 \\
\hline 35 & T.S.K.B. & - & - & + & + & - & - & + & 3 \\
\hline 36 & TAT GIDA & - & + & - & + & - & - & + & 3 \\
\hline 37 & $\begin{array}{l}\text { TAV } \\
\text { HAVALIMAN } \\
\text { LARI } \\
\end{array}$ & + & + & - & + & - & - & + & 4 \\
\hline 38 & $\begin{array}{l}\text { TEKFEN } \\
\text { HOLDING }\end{array}$ & + & - & - & - & - & + & + & 3 \\
\hline 39 & $\begin{array}{ll}\text { TOFAS } & \text { OTO. } \\
\text { FAB. } & \\
\end{array}$ & - & - & - & + & + & + & + & 4 \\
\hline 40 & TUPRAS & - & + & + & - & + & - & + & 4 \\
\hline 41 & \begin{tabular}{|l|} 
TURK HAVA \\
YOLLARI \\
\end{tabular} & + & + & + & - & - & - & - & 3 \\
\hline 42 & \begin{tabular}{|l|} 
TURK \\
TELEKOM \\
\end{tabular} & - & + & - & + & - & + & - & 3 \\
\hline 43 & \begin{tabular}{|l|} 
TURK \\
TRAKTOR
\end{tabular} & + & + & + & - & + & + & + & 6 \\
\hline
\end{tabular}




\begin{tabular}{|l|l|c|c|c|c|c|c|c|c|}
44 & TURKCELL & + & + & + & - & + & - & - & 4 \\
\hline 45 & $\begin{array}{l}\text { ULKER } \\
\text { BISKUVI }\end{array}$ & + & + & + & + & - & - & + & 5 \\
\hline 46 & $\begin{array}{l}\text { VAKIFLAR } \\
\text { BANKASI }\end{array}$ & + & + & + & - & + & + & + & 6 \\
\hline 47 & VESTEL & + & + & + & - & - & - & + & 4 \\
\hline 48 & $\begin{array}{l}\text { VESTEL } \\
\text { BEYAZ ESYA }\end{array}$ & + & + & + & - & - & - & + & 4 \\
\hline 49 & $\begin{array}{l}\text { YAPI VE } \\
\text { KREDI BANK. }\end{array}$ & + & + & - & - & + & - & + & 4 \\
\hline 50 & $\begin{array}{l}\text { ZORLU } \\
\text { ENERJI }\end{array}$ & + & + & + & - & - & + & + & 5 \\
\hline & TOPLAM & 36 & 41 & 31 & 16 & 22 & 27 & 43 & \\
\hline
\end{tabular}

Analiz sonuçlarına göre incelemeler yapıldığında bütün firmaların çoğunluk özellikleri taşıyan vizyon bildirimlerine sahip oldukları söylenebilir. Yine analiz sonuçlarına göre firmaların hepsinin vizyon ifadesine sahip olması da sürdürülebilirlik endeksi içerisinde yer alan firmaların geleceğe yönelik bakış açılarını dikkate alan bir konumda oldukları sonucuna ulaştırmaktadır. Elde edilen veriler incelenerek farklı sonuçlara da ulaşılabilecektir. Tablo 3 firmaların vizyonlarının barındırdıkları özelliklerin sayısını göstermektedir.

Tablo 3: Firmaların Vizyonlarında Bulunan Özelliklerin Sayısı

\begin{tabular}{|c|c|c|}
\hline Özellik Sayısı & Firma Sayısı (n) & Yüzde (\%) \\
\hline 1 & - & - \\
\hline 2 & - & 20 \\
\hline 3 & 10 & 46 \\
\hline 4 & 23 & 18 \\
\hline 5 & 9 & 14 \\
\hline 6 & 7 & 2 \\
\hline 7 & 1 & $\mathbf{1 0 0}$ \\
\hline Toplam & $\mathbf{5 0}$ & \\
\hline
\end{tabular}

Tablo 3 verileri dikkate alındığında toplam firma sayısının \%46'sı 4 özelliği barındıran vizyon ifadelerine sahiptir. Ayrıca 4 ve 4 'ten fazla özelliğe sahip firma sayısı 40 olarak görülmekte ve bu değer toplam firmaların \% 80'ini oluşturmaktadır. Ancak bütün özellikleri barındıran firma sayısı ise sadece 1 olarak görülmektedir. Bu durum diğer firmaların vizyonlarını revize etmelerine çağrışım yapmaktadır. Yine bütün firmalar göz önüne alındığında en az 3 özelliğin vizyon ifadelerinde yer alması ve 1 veya 2 özellik seçeneğinin boş olması firmaların vizyon bildirimlerine önem gösterdiğini ve hazırlarken literatürde belirlenmiş olan kurallara kısmen de olsa uygun davranıldığını göstermektedir. Genel olarak bakıldığında 4 ifadenin yer aldığı firma sayısının 23 olması umut ışığı olarak kabul edilebilmektedir. Bütün özelliklerin 6 veya 7 tanesini vizyon içeriğinde barındıran firma sayısı ise 8 olarak görülmektedir. Bu rakamın beklenen düzeyden bir miktar düşük olması firmaların vizyon ifadelerine yönelik daha fazla önem vermesi gerektiği düşüncesini desteklemektedir.

Yapılan analiz ve incelemelere daha kapsamlı ve ayrıntılı bir bakış açısı ile bakıldığında, işletmelerin vizyonlarının içinde barındırdıkları özellikler çerçevesinde bir inceleme yapmak gerekmektedir. Bu sebeple Tablo 4'te işletmelerin vizyon ifadelerinde bulunan özellik sayıları gösterilmektedir. 
S. Acar $11 / 1$ (2019) 202-215

Tablo 4: Firmaların Özellikleri Bulundurma Sıklığı Tablosu

\begin{tabular}{|l|c|c|}
\hline Özellik & Bulundurma Sayısı (n) & Yüzde (\%) \\
\hline İdealist & 36 & 16,7 \\
\hline Özgünlük & 41 & 19,0 \\
\hline Ayırt Edicilik & 31 & 14,4 \\
\hline Çekicilik & 16 & 7,4 \\
\hline Kısalık & 22 & 10,2 \\
\hline İlham Vericilik & 27 & 12,5 \\
\hline Gelecek Tanımlayıc1 & 43 & 19,9 \\
\hline Toplam & $\mathbf{2 1 6}$ & $\mathbf{1 0 0}$ \\
\hline
\end{tabular}

Tablo 4'teki veriler ışı̆̆ında vizyonların en fazla barındırdığı özellik olarak \%19,9 oranı ile gelecek tanımlayıcılık özelliği dikkat çekmektedir. Vizyon ifadesinin firmanın geleceğe bakış açısını yansıtması açısından bu özelliğin vizyon bildirimlerinde en fazla bulunan özellik olması firmaların vizyon ifadesinin amacının ne olduğu konusunda bilgili olduğu düşüncesini belirtmektedir. Aynı zamanda gelecek tanımlama seçeneğine çok yakın oranlarda yer alan özgünlük özelliği de firmaların farklılaşma yönünde çalışmalar yapmanın önemine vurgu yaptığı şeklinde yorumlanabilir. Bu günün rekabetçi piyasalarında farklılaşma oranı ne oranda yükselirse firmanın elde edeceği fayda o oranda yükseltilebilecektir. Bu sebeple özgünlük büyük önem kazanmaktadır. Vizyon ifadelerinin en az barındırdığı özellik ise \% 7,4 ile çekicilik özelliği olmaktadır. Firmalar çekicilik gibi müşteriye yönelik ifadeleri vizyon ifadelerinden daha çok neden var olduğunu ifade ettiği misyon ifadelerinde yer vermekte ise de bu çalışma da o konu ile ilgili bir inceleme yapılmayacaktır. Ayrıca idealist özellikte olan vizyon ifadelerinin \%16,7 olması da firmaların belirledikleri ideal düşünceleri vizyon ifadelerinde sunmalarının gelecek yönünden büyük katkılar sağlayacağı düşünülmektedir.

\section{Sonuç ve Öneriler}

Vizyon ifadesi, bir firmanın geleceğe yönelik olarak ileride olmak istediği noktayı net bir biçimde ortaya koyabileceği ve paydaşlarına kendini ve hedeflerini net olarak ifade edebileceği en önemli stratejik enstrümanlardan biridir. Bu sebeple firmalar vizyon ifadelerine büyük önem göstererek hazırlamalıdır. Vizyon ifadesi müşterilerin gözünde firmanın hangi noktada olacağına dair büyük ipuçları veren bir yapı oluşturmaktadır. Stratejik yönetim sürecinde bulunan ve geleceğe yönelik stratejik hedefleri, amaçları ve geçmişten gelen ve geleceğe taşınması gereken değerleri olan firmaların vizyon ifadelerine büyük önem göstermesi gerekir.

Stratejik yönetim sürecinin en önemli adımı olan stratejik bilinç vizyon ifadesinin net bir biçimde belirlenmesi ve firmanın gelecekteki olmasını arzu ettiği noktanın netleşmesini de içermektedir. Bu sebeple stratejik yönetim sürecinde olmak isteyen firmaların vizyon ifadelerini belirleyip bütün paydaşları ile paylaşmaları ve özellikle çalışanların özümsemesine büyük önem vermeleri gerekmektedir.

Yapılan bu çalışmanın da temel amacını teşkil eden en önemli nokta vizyon ifadelerinin literatürdeki özellikleri taşıma oranları ve geleceğe yönelik beklentilerin karşılanma durumlarıdır. Bu sebeple stratejik yönetim sürecindeki firmaları vizyon ifadelerini belirlemeleri ve vizyon belirleme sürecinde de literatürde kabul gören özelliklerin vizyon ifadesinin içeriğinde yer almasına dikkat etmeleri önemlidir.

Analizler sonucu elde edilen veriler ışığında BİST Sürdürülebilirlik Endeksinde 2018 yılı ve 2019 yılı arasında endekste yer alacak olan 50 firmanın vizyon ifadeleri yukarıda belirtilen 7 özellik bağlamında içerik 
analizine tabi tutulmuş ve bazı sonuçlara ulaşılmıştır. Bu sonuçlar ile ilgili olarak elde edilen bulgular üzerinde bir tartışma sonucu durumlar netleştirilmiş ve önerilerde bulunulmuştur.

Eleştirel bir bakış açısı çerçevesinde elde edilen bulgular incelenmiş ve şu sonuçlara ulaşılmıştır.

- Analize dahil edilen 50 firmanın bütün hepsinin vizyon ifadesinin yer alması firmaların geleceğe yönelik olarak vizyon ifadesine büyük önem verdiklerini göstermektedir. Bu durum stratejik yönetim sürecinin ne denli önemli görüldüğünü de göstermektedir.

- Akgemci ve Güleş (2009) tarafından literatüre kazandırılan ve bu çalışmanın da inceleme kriteri olan 7 maddenin vizyon ifadelerinde yer alma sayılarına bakıldığında 40 firmanın 4 ve 4 'ten fazla ifadeye sahip vizyonlarının olduğu tespit edilmiştir. Bu gösterge araştırmaya dahil edilen firmaların, belirlenmiş olan 7 özelliğe göre vizyon ifadelerini belirlemiş olabileceğine işaret etmektedir. Aynı zamanda hiçbir firmanın 3 özellikten daha azını vizyon ifadelerinde barındırmadığının görülmesi de firmaların geleceğe büyük önem verdikleri ve özellikleri benimsedikleri sonucuna ulaşılmasına yardımcı olmaktadır. Bu sonuçlar Latif ve Muslu (2015) tarafından yapılan analizin sonuçları ile paralellik göstermektedir.

- Firmaların belirlenmiş olan 7 özelliği vizyon ifadelerinde bulundurma sıklıkları dikkate alındığında en yüksek yer alma sayısına sahip olan özellik 43 firmanın vizyonunda yer alan gelecek tanımlayıcılık özelliğidir. Vizyon ifadesinin temel özelliklerinden biri olan geleceğe yönelik hedef, amaç ve değerlerin aktarılması düşüncesi bu ifade ile netleşmekte ve araştırmaya alının firmaların büyük çoğunluğunun vizyon ifadelerinde geleceğe yönelik ifadelere yer verdiği görülmektedir. Ayrıca özgünlük ve idealistlik özelliklerinin de bir çok firmanın vizyon ifadesinde yer alması sürdürülebilirlik endeksinde yer alan firmaların gerçekten geleceğe yönelik idealleri olan ve özgün olan firmaları kapsadığını göstermektedir.

Yapılan analizin ortaya koyduğu sonuçlara odaklanılarak firmalara bazı önerilerde de bulunulmuştur.

- Öncelikle geleceğe yönelik olarak belirlenmesi gereken vizyon ifadesinin gerektiği gibi gelecekte ulaşılabilecek noktalara işaret etmesi gerekliliği büyük önem taşımaktadır. Oluşturulan vizyon ifadelerinin gelecek yönelimli ve özellikle çalışanları daha önceden belirlenmiş hedef ve amaçlara yöneltici ve motive edici ifadelerle bezenmesi önemlidir.

- Stratejik yönetim sürecinin en önemli adımlarından biri olan vizyon ifadesi sadece yazılı bir metin olmaktan çok bütün paydaşların özümsemesi gereken ve üst yönetiminden en alt kademedeki çalışanına kadar her bir çalışanın vizyon ifadesini anlaması ve işlemlerini bu vizyon çerçevesinde yapması büyük önem taşımaktadır. Bu sebeple vizyon ifadesinin içeriğinde yer alan özellikler çalışanları motive edici ve bilgilendirici niteliklerde olmalıdır.

- Analiz sonuçlarına göre 50 firmanın 28 tanesinin vizyon bildirimleri kısalık özelliğini yansıtmamaktadır. Vizyon ifadesi içeriğinde barındırdığı özellikleri en kısa bir biçimde aktardığı kadar akılda kalıcıdır. Bu sebeple firmalar vizyon ifadesi belirlerken mümkün olan en az kelime ile en yüksek açılamayı yapmaları gerekmektedir.

Sonuç olarak analiz edilen firmaların vizyon ifadeleri Akgemci ve Güleş (2009)'in belirlediği ifadeler yönüyle incelenerek çoğu firmanın bu ifadeleri anımsatan kelimeler kullandığı ve bir vizyonda olması gereken ifadeler mantığ ile çelişmeyen vizyon ifadelerinin olduğu tespit edilmiştir. Literatürde yer alan bazı araştırmaların (Latif \& Muslu, 2015; Tatlı \& Üstün, 2018; Erden Ayhün \& Çavuşgil Köse, 2018) sonuçları ile paralellik gösteren bir sonuç elde edilmiştir. Vizyon ifadelerinin ideal bir vizyon ifadesinde yer alması gereken ifadeler yönüyle ideal vizyon tanımına çoğu firmanın vizyonunun uygun olduğu düşünülmektedir. Gelecekte yapılacak çalışmalara yön verici olarak endeks içi ve dışında yer alan firmaların vizyon ifadeleri karşılaştırmalı bir analize tabi tutularak endeksin vizyon belirleme üzerindeki etkileri incelenebilir. Ayrıca vizyon ve misyon ifadeleri ile de daha kapsamlı yönden firmaların stratejik yönelimleri ortaya konabilir. 


\section{Kaynakça}

Akgemci, T., \& Güleş, H. K. (2009). İşletmelerde Stratejik Yönetim. Ankara: Gazi Kitabevi.

Akgemci, T., Çelik, A., \& Ertuğrul, Ü. G. (2004). Vizyon Sahibi Örgütlerin Özellikleri: Konya Sanayi İşletmelerinde Yapılan Bir Araştırma. Selçuk Üniversitesi Soyal Bilimler Dergsi , 1-28.

Alkoç, G. P. (2010). Misyon ve Vizyon ifadelerinin İşletme Stratejisindeki Yeri ve İşletme Performansı Üzerindeki etkileri. İstanbul: İstanbul Üniversitesi Sosyal Bilimler Enstitüsü İşletme Anabilim Dalı Yönetim ve Organizasyon Bilim Dalı, Yüksek Lisans Tezi.

Ateş, A. (2016). Türkiye'deki Limanların İnternet Sitelerinde Yer Alan Misyon ve Vizyon Beyanlarının Verimlilik Odaklı İçerik Analizi. Mustafa Kemal Üniversitesi Sosyal Bilimler Enstitüsü Dergisi , 401-415.

Collins, J. C., \& Porras, J. I. (1996). Building Your Company's Vision. Harvard Business Review .

Dinler, A. M. (2009). Stratejik Yönetim Sürecinde Vizyon ve Misyon. Paradoks Ekonomi, Sosyoloji ve Politika Dergisi , 1-8.

Doğan, S., \& Hatipoğlu, C. (2009). Küçük ve Orta Boy İşletmelerde Vizyon Açıklamasının İşletmenin Performansına Etkisine İlişkin Bir Araştırma. Atatürk Üniversitesi İktisadi ve İdari Bilimler Dergisi , 81-99.

Erden Ayhün, S., \& Çavuşgil Köse, B. (2018). Misyon Ve Vizyon İfadelerinin Değerlendirilmesi: Türk Yiyecek-İçecek İşletmelerinde Bir Araştırma. BMIJ , 524-549.

George, S. (1997). Focus Through Shared Vision . NATIONAL PRODUCTIVITY REVIEW , 65-74.

Güney, C. (2015). BİsT 100 Endeksinde Yer Alan İşletmelerin Misyon ve Vizyon Bildirimlerinde Çevre. The Journal Of Academic Sosial Science ASOS JOURNAL , 349-356.

Holsti, O. R. (1969). Content Analysis for the Social Sciences and Humanities. Addison Wesley.

İnce, A. R. (2015). Türkiye'nin İkinci 500 Büyük Şiirketinin Misyon ve Vizyon İfadelerine Göre Girişimcilik Özellikleri. Niğde Üniversitesi İktisadi ve İdari Bilimler Fakütesi Dergisi , 143-155.

İslamoğlu, A. H. (2011). Sosyal Bilimlerde Araştırma Yöntemleri. İstanbul: Beta Yayın.

Kantabutra, S. (2008). What Do We Know About Vision? The Journal of Applied Business Research - Second Quarter , 127-138.

Karaman, A. (2005). Vizyon Yönetimi, Nasıl ve Niçin? İstanbul: IQ Yayıncılık.

Kılıç, A., Eren, H., \& Gürsoy, A. (2014). Yenilikçilik Faktörlerinin Örgütlerin Vizyon ve Misyon İfadelerindeki Varlığı; Fortune Türkiye İlk 100 Firma Örneği. İşletme Araştırmaları Dergisi , 36-68.

Kılıç, M. (2010). Stratejik Yönetim Sürecinde Değerler, Vizyon ve Misyon Kavramları Arasındaki İlişki. Sosyo Ekonomi Dergisi , 81-98.

Kurtuluş, K. (2010). Araştırma Yöntemleri. Ankara: Türkmen Kitabevi.

Lamba, M. (2014). Büyükşehir Belediyelerinde Geleceğe Bakış: Stratejik Planlar Üzerinden Bir İnceleme. Uluslararası Alanya İşletme Fakültesi Dergisi , 83-96.

Latif, H., \& Muslu, Ş. (2015). Türk İşletmelerinin Mziyon ve Vizyon Kavramlarında Anlam Kargaşası. İ. Ü. İsletme Fakültesi İşletme İktisadı Enstitüsü Yönetim Dergisi , 12-32.

Muslu, Ş. (2014). Örgütlerde Misyon ve Vizyon Kavramlarının Önemi. HAK-İŞ Uluslararası Emek ve Toplum Dergisi , 150-171.

Ocak, M., Güler, M., \& Basım, N. H. (2016). Türk Savunma Sanayi Firmaları Vizyon ve Misyon İfadelerinin İçerik Analizi. Yönetim ve Ekonomi Dergisi , 503-518.

Önen, V. (2017). Vizyon ve Misyon İfadelerinn İçerik analizi: Türk ve Avrupa Havayolu İşletmeleri. Uluslararası Sosyal Bilimler Dergisi , 1-15.

Özer, M. A. (2010). İşletmelerin Geleceği İçin Yol Haritası: Vizyon Yönetimi. Çimento İşveren Dergisi , 4-21. 
Pearce, J. A., \& David, F. (1987). Corporate Mission Statements: The Bottom Line. Academiy Of Management Executive , 109-116.

Quıgley, J. V. (1998). Vizyon Oluşturulması Geliştirilmesi ve Korunması. (B. Çelik, Çev.) İstanbul: Yeni Çizgi Yayın Dağıtım.

Tatlı, M., \& Üstün, F. (2018). BİST 100 Endeksindeki Firmaların Misyon, Vizyon, Örgütsel Değer ve Stratejik Amaçlarının İçerik Analizi. Ekonomi, Politika \& Finans Araştırmaları Dergisi , 18-31.

Türk Dil Kurumu. (2018). http://www.tdk.gov.tr. Retrieved 2018 йил 01-11 from Türk Dil Kurumu: http://www.tdk.gov.tr/index.php?option=com_gts\&arama=gts\&guid=TDK.GTS.5bdae2270e5539.21007 637

Ülgen, H., \& Mirze, S. K. (2013). İşletmelerde Stratejik Yönetim. İstanbul: Beta Yayınevi. 